\title{
Nasal carriage of Staphylococcus aureus and cross- contamination in a surgical intensive care unit: efficacy of mupirocin ointment
}

\author{
D. Talon, ${ }^{*}$ C. Rouget, $\dagger$ V. Cailleaux, ${ }^{*}$ P. Bailly, ${ }^{*}$ M. Thouverez, ${ }^{*}$ \\ F. Barale $\nmid$ and Y. Michel-Briand*
}

\begin{abstract}
* Laboratoire de Bactériologie-Hygiène and Service de †Réanimation, Faculté de Médecine, Hôpital Yean Minjoz, 25030 Besancon, France
\end{abstract}

\author{
Accepted for publication 9 February 1995
}

\begin{abstract}
Summary: A six month prospective study was carried out in a surgical intensive care unit (SICU) of a university hospital to assess the incidence and routes of exogenous colonization by Staphylococcus aureus. A total of 157 patients were included in the study. One thousand one hundred and eleven specimens (nasal, surgical wound swabs, tracheal secretions obtained on admission and once a week thereafter, and all clinical specimens) were collected over a four month period from patients without nasal decontamination (A). They were compared with 729 specimens collected over a two month period from patients treated with nasal mupirocin ointment (B). All $S$. aureus strains were typed by restriction fragment length polymorphism (RFLP) pulsed-field gel electrophoresis after SmaI macrorestriction. The nasal colonization rates on admission were 25.5 and $32.7 \%$ in groups $A$ and $\mathrm{B}$, respectively. Thirty-one untreated patients $(31 \cdot 3 \%)$ and three patients $(5 \cdot 1 \%)$ treated with nasal ointment, acquired the nasal $S$. aureus in the SICU $(P=0.00027)$. Nasal carriers were more frequently colonized in the bronchopulmonary tract $(\mathrm{Bp})$ and surgical wound $(\mathrm{Sw})(62 \%)$ than patients who were not nasal carriers $(14 \%)(P<0 \cdot 00001)$. The patterns were identical for nasal, $\mathrm{Bp}$ and $\mathrm{Sw}$ strains from the same patient. RFLP analysis characterized seven epidemic strains of methicillin-resistant $S$. aureus (MRSA) which colonized $60 \%$ of group A and $9 \%$ of group B patients $(P<0.00001)$. The bronchopulmonary tract infection rate was reduced in group $\mathrm{B}(P=$ 0.032 ). In conclusion, in an SICU, nasal carriage of $S$. aureus appeared to be the source of endogenous and cross-colonization. 'The use of nasal mupirocin ointment reduced the incidence of $\mathrm{Bp}$ and $\mathrm{Sw}$ colonization, as well as the MRSA infection rate.
\end{abstract}

Keywords: S. aureus; surgical ICU; nasal carriage; mupirocin.

\section{Introduction}

It is now clear that methicillin-resistant strains of Staphylococcus aureus are as pathogenic as methicillin-sensitive strains. ${ }^{1}$ Severe staphylococcal

Correspondence to: D. Talon, Laboratoire de Bactériologie-Hygiène, Hôpital Jean Minjoz, Bd Fleming, 25030 Besançon, France. 
infections are an increasing problem, particularly in intensive care and burns units ${ }^{2}$ where methicillin-resistant $S$. aureus (MRSA) are responsible for $30-60 \%$ of such infections. ${ }^{3-5}$ In our university hospital, MRSA colonization is endemic, with grouped cases and sudden onset, suggesting cross-colonization. ${ }^{3,4,6-8}$ MRSA-induced morbidity and mortality, ${ }^{9}$ first observed in Europe, are now widespread in many countries (Australia, America and Africa).$^{10-12}$ Nasal carriage is the principal endogenous reservoir for infection of patients in surgical wards, as demonstrated by phage typing, ${ }^{7}$ and patients with chronic renal failure on maintenance haemodialysis. ${ }^{13}$ Nasal mupirocin in these patients leads to total eradication of $S$. aureus nasal carriage, a $4 \cdot 26$-fold reduction in the incidence of bacteraemia and a substantial cost saving. ${ }^{15}$ Detection and treatment of nasal carriers with intranasal mupirocin, associated with other measurcs contributcd to the control of large epidemic of MRSA. ${ }^{16,17}$ Hospitalization in a surgical intensive care unit (SICU) is associated with numerous risk factors for infection with $S$. aureus, i.e. the number of care procedures, proximity of colonized/ infected patients, presence of foreign materials and surgical wounds, and lengthy antibiotic therapy. ${ }^{18,19}$ Tracheal tubes and surgical wounds, as well as staff and patients' nares, are frequently colonized and are thus potential reservoirs for cross-infection. ${ }^{14,20-23}$ With the advent of molecular biology, scveral, highly discriminatory techniques, based on DNA polymorphism, have been developed for strain comparisons in epidemiological studies. ${ }^{24-26}$ As a result, the incidence of cross-colonization can now be evaluated accurately by genotyping methods. 'I'his six month prospective study was performed to assess the incidence and routes of exogenous colonization and hospital-acquired infections caused by $S$. aureus, and to evaluate the efficacy of nasal mupirocin ointment in reducing cross-colonization in a SICU.

\section{Materials and methods}

Study design

In a two-step prospective study, a total of 1740 specimens, collected from 157 patients admitted to the SICU (15 beds) of the University Hospital of Besançon, France, were screened for the presence of $S$. aureus. Nasal and surgical wound swabs and tracheal secretions were collected on admission and once a week during hospitalization in the SICU, together with all clinical specimens. Over a four month period 1011 specimens were collected from patients without nasal decontamination (A). During the second period, 729 specimens were collected over a two month period from patients treated with nasal mupirocin ointment (B). All S. aureus strains were typed. Nasal ointment was applied twice a day in each nostril for the first week, beginning on the day of admission and continuing whatever the screening results. 


\section{Bacteriological techniques}

Specimens were cultured using standard blood agar (blood agar base $+7 \%$ horse blood) and Chapman agar (both freshly prepared). Plates were incubated in air at $37^{\circ} \mathrm{C}$ for $48 \mathrm{~h}$. $S$. aureus was identified by colony morphology and by the slide and tube coagulase tests. Methicillin sensitivity was checked at $30^{\circ} \mathrm{C}$ by the conventional Kirby-Bauer disc-diffusion method.

\section{Epidemiologic genotyping}

Unsheared DNA was prepared by the method of Prévost et al. ${ }^{27}$ digested with the restriction endonuclease SmaI according to the manufacturer's instructions and subjected to pulsed-field gel electrophoresis (PFGE) using the CHEF-DRII system (BioRad Ltd) (pulse times of $20 \mathrm{~s}$ for $12 \mathrm{~h}$ and then $5-15 \mathrm{~s}$ for $17 \mathrm{~h}$ at $150 \mathrm{~V}$ and $14^{\circ} \mathrm{C}$ ). Gels were stained with ethidium bromide $(0 \cdot 1 \%)$ for $30 \mathrm{~min}$.

\section{Analysis of DNA relatedness}

The electrophoretic restriction patterns (number and size of fragments) were analysed by scanning photographic negatives with a LKB 2222020 Ultrascan laser densitometer (LKB Pharmacia, Uppsala, Sweden) as described by Prévost et al. ${ }^{27}$ The restriction pattern of each strain was compared to the profile of all other strains. The DNA fingerprint of each isolate was scored for the presence or absence of individual bands (negative character: absence of a band; positive character: presence of a band). A similarity index was determined for each pair of strains by the JaccardSneath formula: $S_{(i, j)}=N_{a} /\left(N_{a}+N_{b}\right){ }^{28}$ where $N_{a}$ is the number of characters shared by $i$ and $j$, and $N_{b}$ the number of different characters. We compared intergel restriction fragment length polymorphisms (RFLPs) by including an internal reference strain in each gel. Major restriction genotypes were defined according to Struelens et $a^{29}$ (common restriction patterns differcd by three or fewer fragments and showed a similarity coefficient $>85 \%$ ). Major genotypes were labelled by numerals, and each of their variant subtypes was indicated by a letter suffix.

\section{Definition of cases}

Case definitions were based on Centers for Disease Control (CDC) criteria. ${ }^{30}$ A case of colonization was defined as any patient with a culture positive for $S$. aureus without evidence of tissue invasion.

\section{Statisical analysis}

The two-sided $\chi^{2}$ test and the Fisher's exact two-sided test were used for contingence univariate analysis on a computer Epi-Info 5.01. 


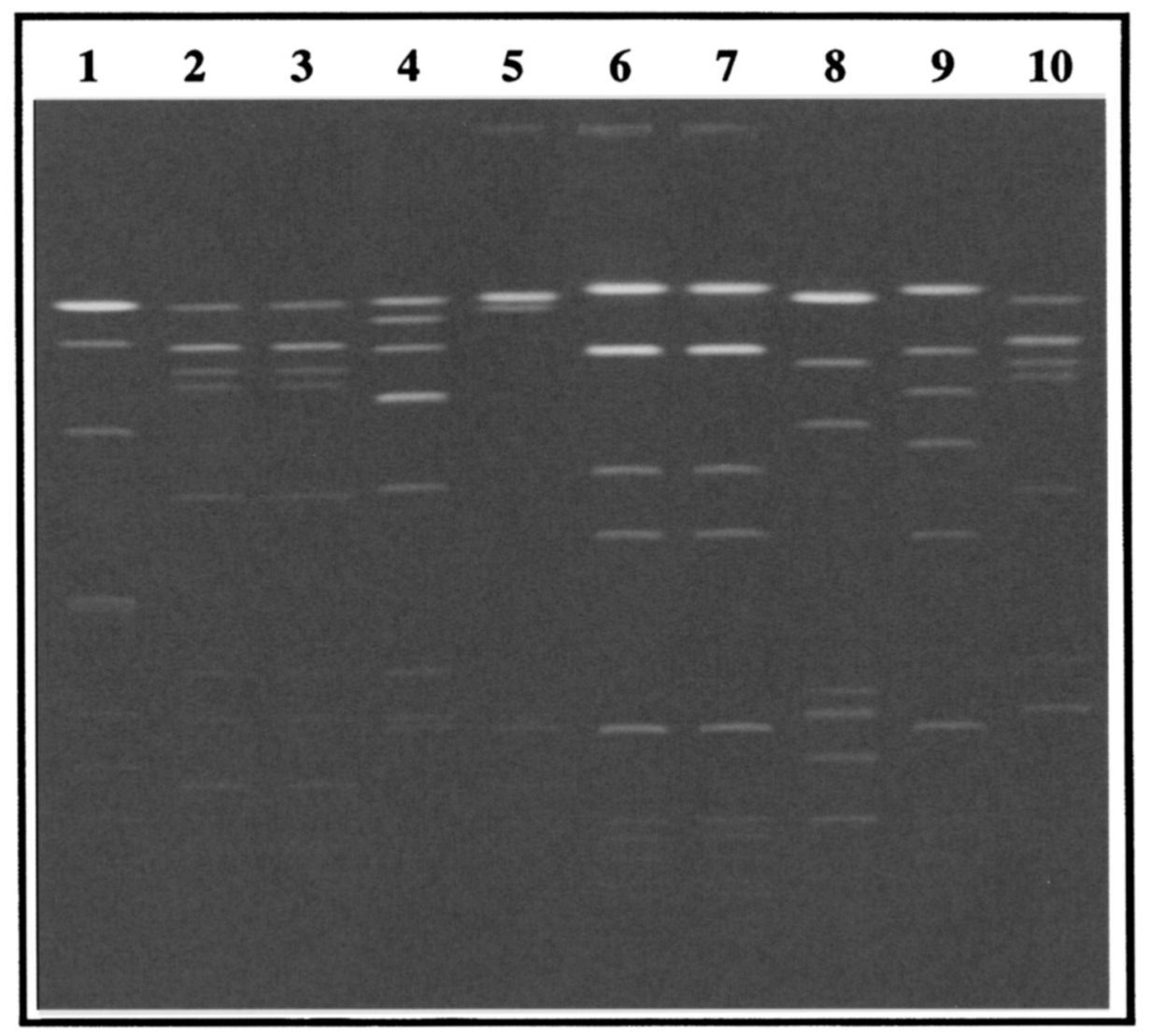

Figure 1. Pulsed-field gel electrophoresis of DraI digested DNA from Staphylococcus aureus isolates. Lane 1: pattern 50; lanes 2 and 3: pattern 4a; lane 4: pattern 51; lane 5: pattern 52; lanes 6 and 7: pattern 47; lane 8: pattern 35; lane 9: pattern 53; lane 10: pattern 4b.

\section{Results}

One hundred and fifty non-repetitive MRSA and methicillin-sensitive $S$. aureus (MSSA) strains showed 65 distinct major DNA patterns (Figure 1). Eleven variant subtypes (types $4 \mathrm{a}-\mathrm{k}$ ) clustered in a clonal group of patterns accounting for 59 isolates. Three other major patterns could be subdivided into types (types $9 a-c, 11 a-b$ and 55a-b). Sixty-one other major patterns clustered at less than $85 \%$ similarity.

The nasal colonization rates on admission were respectively $25.5 \%$ (22 patients) and $32.7 \%$ (19 patients) in periods $A$ and B $(P>0.05) .31 \cdot 3 \%$ of patients $(n=31)$ vs only $5 \cdot 1 \%(n=3)$ acquired the nasal $S$. aureus in the SICU $[P<0.00027 ; \mathrm{RR}=6.05(1.94-18.93)]$. The prevalence of MRSA/ MSSA among nasal isolates was $35 / 18$ and $6 / 16$ in the first and second periods $[P=0.0048 ; \mathrm{RR}=2 \cdot 42(1 \cdot 19-4 \cdot 92)]$. 
Table I. Nasal colonization by epidt mic strains

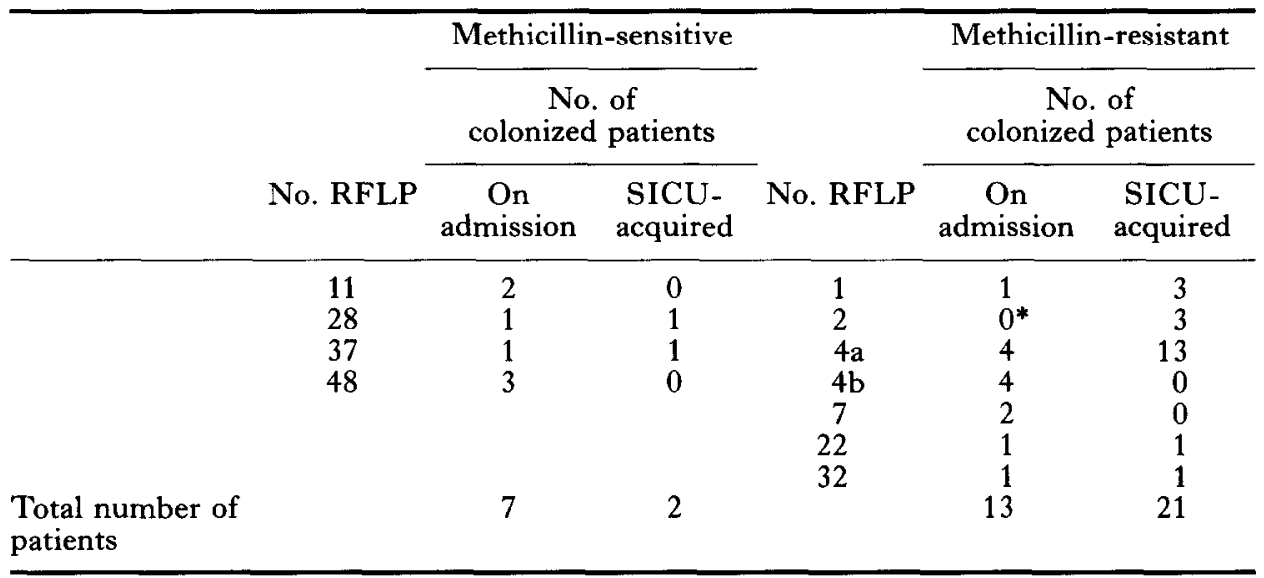

* Pattern present in one patient at the beginning of the study. RFLP, restriction fragment length polymorphism.

SICU, surgical intensive care unit.

Over the six months of this study, 13 patients were colonized with an MRSA on admission to the SICU and 28 paients had an MSSA; 28 patients acquired an MRSA in the SICU and six patients acquired an MSSA $[P<0.0001 ; \mathrm{RR}=2 \cdot 60(1 \cdot 61-4 \cdot 18)]$. Genomic analysis characterized 30 different patterns isolated from single patients and 11 patterns isolated from several patients. As shown in Table I, most, epidemic strains were MRSA before SICU admission as in the SICU and MSSA were sporadic strains. Seven MRSA strains colonized $60 \%$ of nasal carriers in group A and $9 \%$ in group $\mathrm{B}[P=0 \cdot 0001 ; \mathrm{RR}=6.64(1 \cdot 74-25 \cdot 35)]$.

During the two study periods, $S$. aureus colonized various other sites in 54 patients. Among the 75 nasal carriers, 42 were also colonized at another site, as were 12 patients among the 82 who were not nasal carriers $[P<0 \cdot 0001$; $\mathrm{RR}=3.83(2 \cdot 19-6 \cdot 70)]$. Table II shows the distribution of colonized sites. Two, the bronchopulmonary tract and surgical wounds, were colonized by the nasal strain of the same patient $(P<0.0001$ and $P=0.009$, respectively).

The three major SICU-acquired patterns (1,2 and 4a) occurred consecutively during the first period. Among 17 patients with nasal colonization by a pattern $4 \mathrm{a}$ strain, four were carriers on admission: one in February (index case), one in March, one in May (period A) and one in June (period B). Thirteen patients acquired nasal colonization with this pattern in the SICU and three patients acquired it at another site without nasal colonization. The epidemic curve (Figure 2) shows that cross-colonization in the SICU was very frequent during period A (12 patients) and was rapidly reduced during period $B$ (only one case, at the beginning of period $B$ ). In period $\mathrm{B}$, bronchopulmonary tract colonization persisted in three patients, 
Table II. Distribution of Staphylococcus aureus-positive sites

\begin{tabular}{|c|c|c|c|c|}
\hline \multirow[t]{2}{*}{ Specimen } & \multirow{2}{*}{$\begin{array}{l}\text { No. }(\%) \text { of patients } \\
\text { with positive } \\
\text { cultures } \\
(n=160)\end{array}$} & \multicolumn{2}{|c|}{ Nasal colonization } & \multirow{2}{*}{$\begin{array}{c}P \\
(\mathrm{RR})\end{array}$} \\
\hline & & $\begin{array}{l}\text { Positive with } \\
\text { the same strain }\end{array}$ & $\begin{array}{c}\text { Negative or } \\
\text { positive with } \\
\text { another strain }\end{array}$ & \\
\hline Tracheal secretion & $43(26 \cdot 8)$ & 28 & 15 & $\begin{array}{c}<0.0001 \\
(2.38)\end{array}$ \\
\hline $\begin{array}{l}\text { Surgical wound } \\
\text { swab }\end{array}$ & $12(7 \cdot 5)$ & 9 & & $\begin{array}{l}3 \cdot 009 \\
(2 \cdot 18)\end{array}$ \\
\hline Blood & $9(5 \cdot 6)$ & 4 & 5 & NS \\
\hline Vascular line & $5(3 \cdot 1)$ & 2 & 3 & NS \\
\hline Urine & $5(3 \cdot 1)$ & 2 & 3 & NS \\
\hline Rectal swab & $1(0 \cdot 6)$ & 1 & 0 & NS \\
\hline
\end{tabular}

NS, non-significant.

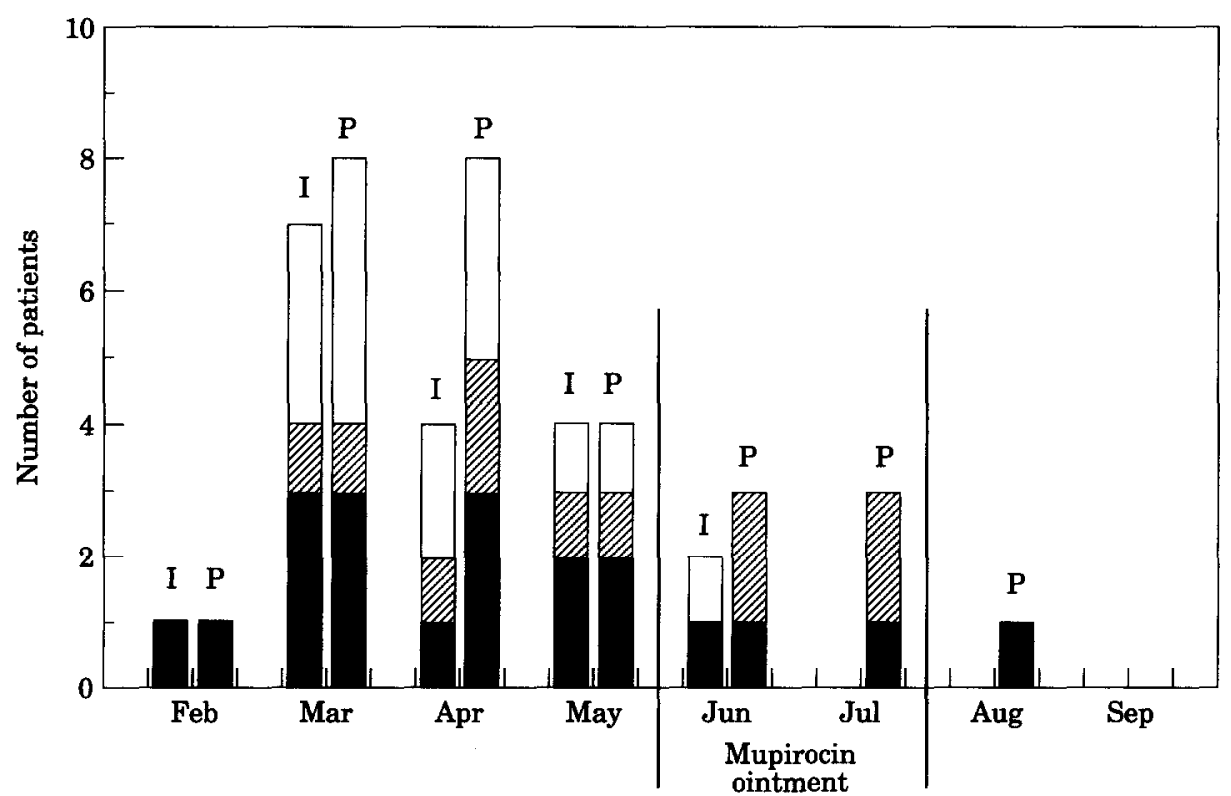

Figure 2. Epidemic curve of 4a pattern. ( $\square$ ), Nasal carriage; (包), other sites of colonization; (I), nasal carriage and other sites of colonization. I, Incidence; P, prevalence.

one with simultaneous nasal colonization. All the strains isolated during both period $A$ and period $B$ were susceptible to mupirocin $\left(\mathrm{CMI}<0.25 \mathrm{mg} \mathrm{l}^{-1}\right)$.

During the study period, we observed no acquired methicillin resistance. Seven patients initially colonized with an MSSA pattern acquired an MRSA with a different pattern in the SICU. Nineteen patients developed an infection with an $S$. aureus strain during period $\mathrm{A}$ and four during period 
Table III. Infections

\begin{tabular}{lccc}
\hline Infections & Period A & Period B & $P$ \\
\hline Pulmonary tract & 13 & 1 & $\mathbf{0 \cdot 0 3 2}$ \\
Bacteraemia/septicaemia & 6 & 1 & NS \\
Surgical wound & 2 & 0 & NS \\
Urinary tract & 2 & 1 & NS \\
Surface & 1 & 1 & NS \\
Vascular line & 1 & 0 & NS \\
\hline
\end{tabular}

NS, non-significant.

$\mathrm{B}[P=0.036 ; \mathrm{RR}=2.78(1 \cdot 00-7 \cdot 78)]$. The incidence of infections was 28 per 100 patients admitted $(n=25)$ before decontamination and $6 \cdot 8$ during the treatment period $(n=4)[P=0.0001 ; \mathrm{RR}=4.0(1 \cdot 83-8.73)]$. The two major infections (Table III) were pneumonia and bacteraemia/septicaemia, and both were reduced during period $\mathrm{B}$, the first significantly $(P=0.032)$.

\section{Discussion}

The epidemiology and routes of MRSA transmission must be identified, in order to control the spread by means of specific measures. ${ }^{31}$ Accurate epidemiologic typing is of primary importance. Markers include the lysotype, serotype and capsular type. Molecular subtyping methods include protein electrophoretyping, ${ }^{32}$ plasmid content and plasmid DNA restriction pattern ${ }^{33,34}$ restriction analysis of total genomic $\mathrm{DNA}^{35}$ and RFLP generated by Southern hybridization with DNA probes. ${ }^{34,35}$ Recently, DNA fingerprinting by PFGE has provided a higher level of strain discrimination. ${ }^{26,36}$ This method is more effective than ribotyping ${ }^{37}$ and polymerase chain reaction genome fingerprinting ${ }^{25}$ in distinguishing between MRSA isolates.

The use of a highly discriminant typing method confirmed that the major vector of MRSA infections in the SICU is cross-colonization and not the selection of resistant mutants of susceptible strains, despite the frequent use of $\beta$-lactam antibiotics. ${ }^{7,38}$ This method also showed that, during period A, the situation was 'pseudo-endemic', as the stable high rate of colonization was due to the successive spread of different epidemic patterns. The staff can be the reservoir for epidemic spread of MRSA ${ }^{14,29,40}$ but this was not the case in our study, as three different strains followed one another during $A$, and only patient decontamination alone was successful during B. Transient hand carriage during the numerous patient care procedures, especially during bronchopulmonary tract and surgical wound care, was probably the source of cross-colonization by a strain with the same DNA pattern.

RFLP PFGE was used for the first time to compare isolates from the nose and other sites. This comparison, with a very effective typing method, 
allowed us to carry out an accurate study of MRSA epidemiology. Colonization of the bronchopulmonary tract before nasal colonization was also found by Walsh et al. ${ }^{21}$ but we demonstrated that the DNA pattern of the bronchopulmonary strains were identical to that of the nasal strains.

Mupirocin ointment applied to the anterior nostrils was very effective in eradicating $S$. aureus nasal carriage $(P=0.00027)$ as previously suggested. ${ }^{17,41-44}$ Nasal decontamination, which has been used with varying degrees of success in several outbreaks, ${ }^{16,45-47}$ significantly reduced the rate of infections and the incidence of pneumonia due to MRSA and MSSA. The three ventilated patients who acquired nasal colonization during period B carried the same strain in the bronchopulmonary tract, and all three strains were mupirocin-susceptible. The presence of the ventilator tube probably explains the recolonization of the nares without selection of mupirocin-resistant strains. ${ }^{48,49}$

Detailed guidelines for the control of epidemic MRSA have been published by the British Society of Antimicrobial Chemotherapy and the Hospital Infection Society. These guidelines emphasize the importance of isolating positive patients, staff hand disinfection, and eliminating skin and nasal carriage. Routine nasal decontamination on admission was effective in reducing colonization and infection rates without screening, isolation measures and skin disinfection. Such a strategy can be used in a single small unit like ours (15 beds) but is more problematic for an entire hospital. The use of mupirocin alone to treat nasal colonized patients delays decontamination and requires strict isolation of patients until clearance swabs have proved negative.

\section{Conclusions}

Nasal carriage appears to be the major source of endogenous and crosscolonization in the SICU. The use of mupirocin nasal ointment reduces the incidence of both colonization and infection. Routine identification and decontamination of nasal carriers on admission, especially after transfer from other units, can probably avoid the spread of $S$. aureus epidemics.

We thank the laboratoires BEECHAM-SEVIGNE for their contribution. A part of this work is supported by INSERM and CNAMTS (Convention no. 3 AM 080).

\section{References}

1. Casewell MW. Epidemiology and control of the 'modern' methicillin-resistant Staphylococcus aureus. F Hosp Infect 1986; Suppl. 7: 1-11.

2. Grosserode MH, Wenzel RP. The continuing importance of Staphylococci as major hospital pathogens. F Hosp Infect 1991; Suppl. 19: 3-17. 
3. Gutmann L. Infections nosocomiales à Staphylococcus aureus methicillino-résistant en réanimation: épidémiologie, facteurs de risque. In Actualités en Réanimation et Urgences. Arnette 1992; 157-169.

4. Bannister BA. Management of patients with epidemic methicillin-resistant Staphylococcus aureus experience at an infectious diseases unit. $\mathcal{F}$ Hosp Infect 1987; 9: 126-131.

5. Boyce JM. Methicillin-resistant Staphylococcus aureus: detection, epidemiology and control measures. Infect Dis Clin N Am 1989; 3: 901-913.

6. Williams REO. Epidemiology of airborne staphylococcal infection. Bacterial Rev 1966; 30: $660-672$.

7. Williams REO, Jevons MP, Shooter RA et al. Nasal staphylococci and sepsis in hospital patients. $B M \mathcal{F} 1959 ; 2$ : 658-662.

8. Shooter RA, Thom BT, Dunkerley DR et al. Preoperative segregation of patients in a surgical ward. BMF 1963; 2: 1567-1569.

9. Jevons MP. "Celbenin"-resistant staphylococci. BMF 1961; 1: 124-125.

10. Price EH, Brain A, Dickson JAS. An outbreak of infection with a gentamicin and methicillin-resistant Staphylococcus aureus in a neonatal unit. $\mathcal{F}$ Hosp Infect 1980; 1 : 221-228.

11. Boyce JM, Causey WA. Increasing occurence of methicillin-resistant Staphylococcus aureus in the United States. Infect Control 1982; 3: 377-383.

12. Rotimi VO, Orebamjo OA, Banjo TO, Onyenefa PI, Nwobu RN. Occurrence and antibiotic susceptibility profiles of methicillin-resistant Staphylococcus aureus in Lagos university teaching hospital. Centr Afr F Med 1987; 33: 95-99.

13. Yu VL, Goetz A, Wagener M et al. Staphylococcus aureus nasal carriage and infections in patients on hemodialysis. Efficacy of antibiotic prophylaxis. $N$ Engl $\mathcal{Y ~ M e d ~ 1 9 8 6 ; ~}$ 315: 91-96.

14. Lidwell OM, Polakoff S, Davies J et al. Nasal acquisition of Staphylococcus aureus in a subdivided and mechanically ventilated ward: endemic prevalence of a single staphylococcal strain. F Hyg (Camb) 1970; 68: 417-433.

15. Boelaert JR, De Baere YA, Geernaert MA, Godard CA, Van Landuyt HW. The use of nasal mupirocin ointment to prevent Staphylococcus aureus bacteriemias in haemodialysis patients: an analysis of cost-effectiveness. $\mathcal{F}$ Hosp Infect 1991; Suppl. 19: 41-46.

16. Coello R, Jiménez J, Garcia M et al. Prospective study of infection, colonization and carriage of methicillin-resistant Staphylococcus aureus in an outbreak affecting 990 patients. Eur F Clin Microbiol Infect Dis 1994; 13: 74-81.

17. Coello R, Fernandez C, Aroyo $P$ et al. Success and failure in the control of methicillinresistant Staphylococcus aureus. In: R Coello, MW Casewell, Eds. Methicillin-resistant Staphylocuccus aureus, pp. 95-98. Tumbridge Wells: Wells Medical Lid 1993; 95-98.

18. Longfield JN, Townsend TR, Cruess DF et al. Methicillin-resistant Staphylococcus aureus: risk and outcome of colonized vs. infected patients. Infect Control 1985; 6: 445-450.

19. Aboukasm AG, Buu-Hoi AY, El Solh Net al. Epidemiological study of Staphylococcus aureus resistance to new quinolones in a university hospital. $\mathcal{F}$ Hosp Infect 1991; 17: 25-33.

20. Dyas AC, Eden PJ, Eastwood D et al. Sources of staphylococcal wound sepsis in surgical patients. $\mathcal{F}$ Hosp Infect 1982; 3: 345-350.

21. Walsh TJ, Vlahov D, Hansen SL et al. Prospective microbiologic surveillance in control of nosocomial methicillin-resistant Staphylococcus aureus. Infect Control 1987; 8: 7-14.

22. Ayliffe GAJ, Babb JR, Collins BJ. Dispersal of Staphylococcus aureus. Lancet 1974; i: 1573 .

23. Lidwell OM, Polakoff S, Jevons MP et al. Staphylococcal infection in thoracic surgery: experience in a subdivided ward. F Hyy (Camb) 1966; 64: 321-337.

24. Richardson JF, Reith S. Characterization of a strain methicillin-resistant Staphylococcus aureus (EMRSA-15) by conventional and molecular methods. F Hosp Infect 1993; 25: $45-52$.

25. Saulnier P, Bourneix C, Prévost G, Andremont A. Random amplified polymorphic DNA assay is less discriminant than pulsed-field gel electrophoresis for typing strains of methicillin-resistant Staphylococcus aureus. F Clin Microbiol 1993; 31: 982-985.

26. Carles-Nurit MJ, Christophle B, Broche S, Gouby A, Bouzigues N, Ramuz M. 
DNA polymorphisms in methicillin-susceptible and methicillin-resistant strains of Staphylococcus aureus. F Clin Microbiol 1992; 30: 2092-2096.

27. Prevost G, Jaulhac B, Piemont Y. DNA fingerprinting by pulsed-field electrophoresis is more effective than ribotyping in distinguishing among methicillin-resistant Staphylococcus aureus isolates. F Clin Microbiol 1992; 30: 967-973.

28. Sneath PH, Sokal RR. 1973. Numerical Taxonomy. San Francisco: Freeman WH and Company, Ed.

29. Struelens MJ, Bax R, Deplano A, Quint WGV, Van Belkum A. Concordant clonal delineation of methicillin-resistant Staphylococcus aureus by macrorestriction analysis and polymerase chain reaction genome fingerprinting. $\mathcal{F}$ Clin Microbiol 1993; 31: 1964-1970.

30. Centers for Disease Control. Outline for surveillance and control of nosocomial infections. Atlanta. US Department of Health. Education and Welfare. Public health service, November 1986.

31. Boyce JM. Methicillin-resistant Staphylococcus aureus: a continuing infection control challenge. Eur $\mathcal{F}$ Clin Microbiol Infect Dis 1994; 13: 45-49.

32. Costas M, Cookson BD, Talsania HG, Owen RJ. Numerical analysis of electrophoretic protein patterns of methicillin-resistant Staphylococcus aureus. F Clin Microbiol 1989; 27: $2574-2581$.

33. Cookson B, Phillips I. Epidemic methicillin-resistant Staphylococcus aureus. J Antimicrob Chemother 1988; 21 Suppl. C: 57-65.

34. Mulligan ME, Arbeit RD. Epidemiologic and clinical utility of typing systems for differentiating among strains of methicillin-resistant Staphylococcus aureus. Infect Control Hosp Epidemiol 1991; 12: 20-28.

35. Jordens JZ, Hall LMC. Characterization of methicillin-resistant Staphylococcus aureus isolates by restriction endonuclease digestion of chromosomal DNA. F Med Microbiol 1988; 27: 117-123.

36. Ichiyama S, Ohta M, Shimokata $K$, Kato N, Takeuchi J. Genomic DNA fingerprinting by pulsed-field gel electrophoresis as an epidemiological marker for study of nosocomial infections caused by methicillin-resistant Staphylococcus aureus. F Clin Microbiol 1991; 29: 2690-2695.

37. Meugnier $\mathrm{H}$, Fernandez MP, Bes $\mathrm{M}$ et al. rRNA gene restriction patterns as an epidemiological marker in nosocomial outbreaks of Staphylococcus aureus infections. Res Microbiol 1993; 144: 25-33.

38. Brumfitt W, Hamilton-Miller J. Methicillin-resistant Staphylococcus aureus. N Engl I Med 1989; 320: 1188-1196.

39. Shanson DC, McSwiggan DA. Operating theatre acquired infection with a gentamicinresistant strain of Staphylococcus aureus: outbreak in two hospitals attributable to one surgeon. $\mathcal{F}$ Hosp Infect 1980; 1: 171-172.

40. Coovadia YM, Bhana RH, Johnson AP, Haffejee I, Marples RR. A laboratory-confirmed outbreak of rifampicin-methicillin-resistant Staphylococcus aureus (RMRSA) in a newborn nursery. F Hosp Infect 1989; 14: 303-312.

41. Casewell MW, Hill RLR. Elimination of nasal carriage of Staphylococcus aureus with mupirocin ("pseudomonic acid")—a controlled trial. $\mathcal{F}$ Antimicrob Chemother 1986; 17: $365-372$.

42. Reagan DR, Doebbeling BN, Pfaller MA et al. Elimination of coincident Staphylococcus aureus nasal and hand carriage with intranasal application of mupirocin calcium ointment. Ann Intern Med 1991; 114: 101-106.

43. Hill RL, Duckworth GJ, Casewell MW. Elimination of nasal carriage of methicillinresistant Staphylococcus aureus with mupirocin during a hospital outbreak. $\mathcal{F}$ Antimicrob Chemother 1988; 22: 377-384.

44. Wenzel RP, Nettleman MD, Jones RN, Pfaller MA. Methicillin-resistant Staphylococcus aureus: implications for the 1990s and effective control measures. Am F Med 1991; 91S3B: 221-227.

45. Blumberg LH, Klugman KP. Control of methicillin-resistant Staphylococcus aureus bacteraemia in high risk areas. Eur 7 Clin Microbiol Infect Dis 1994; 13: 82-85.

46. Valls V, Gomez-Herruz P, Gonzales-Palacios R, Cuadros JA, Romanyk JP, Ena J. Long term efficacy of a program to control methicillin-resistant Staphylococcus aureus. Eur $\mathscr{F}$ Clin Microbiol Infect Dis 1994; 13: 90-95.

47. Pujol M, Pena C, Pallares R, Ayats J, Ariza J, Gudiol F. Risk factors for nosocomial 
bacteremia due to methicillin-resistant Staphylococcus aureus. Eur $\mathcal{I}$ Clin Microbiol Infect Dis 1994; 13: 96-102.

48. Kavi J, Andrews JM, Wise R. Mupirocin-resistant S. aureus. Lancet 1987; 2: 1472.

49. Noble WC, Rahman M, Cookson B, Phillips I. Transferable mupirocin resistance. $\mathcal{F}$ Antimicrob Chemother 1988; 22: 771-772. 